
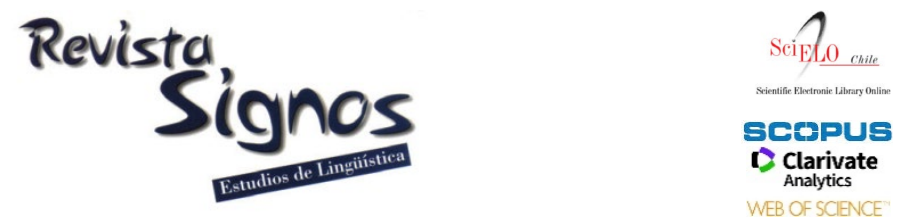

\title{
Introduction to the monographic section: Metadiscourse devices in academic discourse
}

This monograph brings together a collection of studies within the field of corpus linguistics and metadiscourse devices. Each of these articles offers distinct but sometimes shared perspectives on exploring metadiscourse devices in particular textual compilations representative of several academic knowledge domains, e.g. engineering, history, linguistics, medicine and tourism. A description of these corpora is conveniently provided in each of the articles, along with a presentation of the software deployed for corpus management and interrogation.

The articles have been organised considering these textual compilations and the metadiscourse elements under focus. The first two articles - by Alonso-Almeida and by Álvarez-Gil and Domínguez Morales- aim to shed light on the use of modal verbs in academic writing. In the first article, the author reports on the use of modal verbs with dynamic senses in historical texts from a diachronic perspective. The second article focuses on a corpus of academic articles in the field of tourism in order to describe the use of modal verbs to indicate the authors' stance towards the information they offer in the introduction and conclusion sections of their papers. The next two studies -by Skorczynska and Carrió-Pastor and by del Saz- have been conducted within the frame of the *IAMET project, which is a competitive project granted by the Spanish Ministry of Economy and Competitivity (Proyecto: FFI201677941-P) entitled: Identification and analysis of rhetoric elements in Spanish and in English: study of metadiscoursive strategies. This project has given way to and made available a large contrastive corpus of Spanish and English journal articles from several disciplines. The last two contributions to the present issue examine two learner corpora comprising students' productions at different educational levels. Granados and Lorenzo's contribution analyses a corpus consisting of a set of texts produced by secondary school students' learning history as part of a bilingual education programme (CLIL) in Andalusia (southern Spain). López-Ozieblo, on the other hand, carries out a study performed on the written production in L2 of a group of students at the Hong Kong Polytechnic University. 
The interest in the analysis of textual and interpersonal devices in scientific texts, i.e. metadiscourse, is not new, but the number of studies in this area of linguistics keeps growing each year. Evidence of this is the large list of contributions on the topic published in leading peer-reviewed journals and international printing houses (see also Wei, Li, Zhou \& Gong, 2016, for a review). Within the framework of metadiscourse, many academic discourse studies cover the analysis of the style and features of the language of scientific writing from a diachronic and synchronic perspective, describing the way in which the authors elaborate and organise meaning to convey scientific thought in their respective community of practice (Lave \& Wenger, 1991). The presence of metadiscourse devices in academic and technical texts is undeniable, as put forward in Mauranen (1993), Hyland (1998, 2005), Hyland and Tse (2004) and Mur Dueñas (2011), among others. Examples from either a diachronic or a synchronic perspective include Alonso-Almeida (2012, 2015); Alonso-Almeida and Álvarez-Gil (2019); Álvarez-Gil (2020); Bamford and Bondi (2005); Bondi (2017); Bondi and Sezzi (2016); Carrió-Pastor (2016); Gotti (2003, 2008); Halliday (1988, 1989, 1990); Hyland (2005, 2006, 2009); Hyland and Bondi (2006); Moskowich and Crespo (2014); Taavitsainen, Pahta and Mäkinen (2006), Taavitsainen and Pahta (2013) to mention but a few. This type of research may greatly benefit our understanding of contemporary discourse and authorship practices in different fields of knowledge.

Metadiscourse has enjoyed different definitions depending on the nature of the evidence analysed. Williams (1981: 121-122), considers metadiscourse as "writing about writing, whatever does not refer to the subject matter being addressed". This means identifying at least two levels of meaning: (i) the discursive level, which offers the propositional content of a text, and (ii) the metadiscoursive level, which in principle provides the audience with material guiding them through their process of interpretation. Following this distinction, Vande Kopple $(1985,2002)$ and Crismore and Farnsworth (1989) developed their approaches to metadiscourse variously relying on the ideational, interpersonal and textual functions of language proposed by Systemic Functional Linguistics (SFL). In general terms, the ideational function is situated as a primary level and has to do with the propositional material; the interpersonal and textual functions are related to the meta-discourse level. While interpersonal elements indicate different attitudes towards the propositional material, textual elements contribute to unfolding the texts coherently and cohesively. Crismore (1984), for instance, explains this as follows:

"Metadiscourse functions on a referential, informational plane when it serves to direct readers on how to understand the author's purposes and goals, and the primary message by referring to its content and structure. The referring can be on a global or local level. Metadiscourse functions on an expressive or attitudinal plane when it serves to direct readers how to 'take' the author, that is, how to understand the author's perspective 
or stance toward the content or the structure of the primary discourse" (Crismore, 1984: 282).

Mauranen (1993) identifies two main trends in metadiscourse studies: integrative and non-integrative (see also Ädel \& Mauranen 2010). The integrative approach takes the textual interaction between writer and reader as a defining characteristic. In contrast, the non-inclusive approach considers metadiscourse as a more restricted concept that only looks at reflexivity, i.e. the ability of language to comment on one's own language (Ädel, 2010). Non-inclusive approaches tend to define metadiscourse as:

"reflexive linguistic expressions referring to the evolving text per se or its linguistic form, including references to the writer persona and the imagined reader qua reader and the reader of the current text" (Ädel, 2005: 154).

Hyland (2005) adopts an integrative approach to metadiscourse. He acknowledges that there is no unique definition of the term and that the notion: "has always been something of a fuzzy term, often characterised as simply 'discourse about discourse' or 'talk about talk'" (Hyland, 2005: 16), However, he sees great consensus on metadiscourse as "material which goes beyond the subject matter to signal the presence of the author" (Hyland, 2005: 35) and adopts a comprehensive definition of the term:

"Metadiscourse is the cover term for the self-reflective expressions used to negotiate interactional meanings in a text, assisting the writer (or speaker) to express a viewpoint and engage with readers as members of a particular community" (Hyland, 2005: 37-38).

This definition is clearly related to several others in the literature, and it highlights the value of the interpersonal dimension of interaction in the development and elaboration of knowledge.

The integrative approach to metadiscourse proposed by Hyland (2005) includes two dimensions: the interactive and the interactional. The former includes code glosses, endophoric markers, evidentials, frame markers and transition markers. The latter involves attitude markers, boosters, engagement markers, hedges and selfmention. Readers are an integral part of specialised discourse, and authors seek to promote and guide effective interaction with their readers. The use of metadiscourse devices is, therefore, essential in this regard. In addition, these mechanisms enable to highlight the authors' epistemological positioning and preferences while they also organise and develop information in a logical way. Mur-Dueñas (2011) explains the relation between the interactive and the interactional dimensions of metadiscourse in the following terms: 
"Thus, both interactive metadiscourse features (intended to organise and shape the material in the light of the readers' likely needs and expectations) and interactional metadiscourse features (aimed at portraying the scholars as authors and at binding writer and reader together) are a response to the interpersonal component of writing" (Mur-Dueñas, 2011: 3069).

Metadiscourse is clearly associated with other such notions as epistemic stance (Biber \& Finegan, 1989), commitment (Caffi, 2007; Del Lungo Camiciotti, 2008), mitigation (Martín Martín, 2008; Alonso-Almeida, 2015), reinforcement or strengthening (Brown, 2011), intensification (González, 2015), authority, involvement and hedging (Hyland, 1998, 2005), assessment (Goodwin, 2006), modality and evidentiality (Chafe, 1986; Palmer, 2001; Goodwin, 2006; Marín Arrese, 2009; CarrióPastor, 2012; Pic \& Furmaniak, 2012), affect (Martin, 2000; Martin \& White, 2005), and vagueness in language (Cutting, 2007). The truth is that all these notions reflect interpersonality in discourse and they seem to strongly relate to the interactional side of metadiscourse, if this dimension also has an effect on the organisation of the contexts in texts, as shown in Alonso-Almeida and Álvarez-Gil (forthcoming).

The studies included in this issue of Revista Signos. Estudios de Lingüística present different aspects of metadiscourse and illustrate the key role of metadiscoursive practices in structuring texts, supporting authorial accountability, supplying justificatory evidence, and engaging in interaction with readers, among other functional targets.

In the first article, Francisco Alonso-Almeida explores the use of modal verbs from different perspectives in the texts compiled for the Corpus of History of Texts in English (CHET), a subcorpus of the Coruña Corpus of English Scientific Writing (1700900). Following Palmer (2001) in the formulation of his hypothesis, the author states that there is significant use of modal verbs with dynamic senses in these texts. Using a method that includes computerised corpus tools to search and excerpt cases as well as a manual inspection of each one of the occurrences individually, the author seeks to detect the use and function that dynamic modals have in the history texts from the eighteenth and nineteenth centuries. The results of this study are provided on a qualitative and quantitative basis, and they show the potentiality of these modal verbs in developing the argumentation, as the intrinsic and extrinsic features of things and people contribute to elaborating new knowledge as part of a deductive process. Actually, the conclusions report on the close association of dynamic modals with other argumentative and logical devices. In addition to this function of dynamic modality, authors seem to use them to indicate politeness. 
The following article, written by Francisco J. Álvarez-Gil and María Elena Domínguez Morales, also examines modal verb meanings and functions in academic texts but with reference to a different field of knowledge. The corpus of texts analysed comprises article introductions and conclusions written in English and published in leading journals specialising in tourism studies. Within a theoretical framework based primarily on Palmer (2001) and Biber, Johansson, Leech, Conrad and Finegan (1999), the authors' main aim is to show the importance of modal verbs in conveying the authors' stance about propositional content. The article discusses variation in the frequency and use of modal verbs in the introduction and conclusion sections of scientific research articles in terms of their forms and meaning, as well as variation in the functions of modal verbs in these sections. Variation ratios are evaluated using a log-likelihood test to find differences in significance between occurrences in introductions and conclusions.

The primary concern of the next article is the study of variation in the frequencies and pragmatic functions of the metadiscourse markers known as boosters (Hyland, 1997, 1998, 2005; Hyland \& Tse, 2004; Peacock 2006), particularly with regard to their verb forms. To this end, Hanna Skorczynska and María Luisa Carrió-Pastor interrogate three corpora with texts from different fields, namely engineering, medicine and linguistics. The raw count of the occurrences of verb boosters shows, as already proved in previous studies, that there exist differences in the use of these markers according to the nature and academic field to which a text belongs. Nonetheless, the range of verbs found in the different corpora is remarkably similar, pointing to a considerable overlap among them. While this overlap is reported in engineering and medicine, significant variation is described in the domain of linguistics.

María Milagros del Saz' s contribution studies authorial visibility in the introduction and post-methodology sections of research papers from different disciplines. In line with numerous studies on metadiscourse published over the last few decades, the author confirms that academic writing is not entirely impersonal. Following Hyland (2001, 2002), the writers' presence in their texts is seen as part and parcel of academic prose, as authors need to portray a convincing authorial voice, while also being able to present their claims and findings tentatively. The rhetorical elements analysed by Milagros del Saz to determine authorial visibility are basically personal pronouns, and their corresponding determiners, or noun phrases (Tang \& John, 1999; Martínez, 2005; Mur-Dueñas, 2007). Using a multidisciplinary corpus of engineering, medicine and linguistics, she provides interesting findings concerning the presence of selfmentioning pronouns, showing there are significant differences, from a statistical point of view, in both the way and frequency with which authors from each discipline make themselves visible in the different sections under analysis. 
In their study, Granados and Lorenzo examine English L2 connectives in bilingual academic discourse in a learner corpus and describe the longitudinal evolution in the use of English L2 connectives made by students enrolled in a bilingual CLIL programme in the Andalusian secondary education system (Southern Spain) along three years of formal tuition. In order to achieve this goal, the automated tool CohMetrix (McNamara, Louwerse, Cai \& Graesser, 2014) was used. The authors analysed the overall evolution of connectives as well as the evolution of each of the categories of connectives measured by Coh-Metrix (causal, logical, adversative/contrastive, temporal, extended temporal, additive, positive and negative connectives). The results show an increase in the overall use of connectives, indicating that the students are becoming more proficient L2 writers. Their results indicate a development of the learners' historical literacy; they point in particular at a transition from narrative to expository texts, as manifested by a particular increase in the students' use of causal, adversative/contrastive and extended temporal connectives.

Finally, Renia Lopez-Ozieblo offers a study based on SFL theory and pedagogy, in particular the $3 \times 3$ matrix toolkit for academic literacy (Humphrey, Martin, Dreyfus \& Mahboob, 2010) and the Teaching and Learning Cycle (Callaghan \& Rothery, 1988). She analyzes the productions of university students of the Hong Kong Polytechnic University in order to identify successful moves expressing field, manner and tenor in the genre of argumentative essays. The method deployed involves different actions. Academic writing samples were analysed in class in order to supply specific writing instruction to students before they started constructing their texts independently. Students' confidence levels on their writing abilities were measured through the use of knowledge surveys at the beginning and end of the term. The results of this study suggest that there was an increase in the students' confidence in their writing abilities and that their grades were better than those of the previous cohort.

The volume thus covers different descriptive and applied perspectives on aspects of metadiscourse, paying particular attention to modals, boosters and other markers of authorial presence, as well as to connectives and elements of textual organization. The topic is so central to academic discourse studies that it could never be presented comprehensively. The papers we have collected, however, offer at least an idea of the range of perspectives involved.

While thanking the authors for their contribution, we would like to underline that without the invaluable assistance of the journal's editorial team and the anonymous reviewers, this monograph would not have been possible. For this reason, we would like to thank all of them for their efforts and dedication, as their work has helped to ensure the quality of this monograph.

Finally, we would like to express our deepest gratitude to the late Dr Giovanni Parodi, former Editor-in-Chief of the journal Revista Signos. Estudios de Lingüistica, for 
his kindness and professionalism, and for the opportunity to publish this monograph in the journal. His value as a linguist and as a human being has left a deep impression on all those who had the pleasure of collaborating with him at some point. We feel very honoured to be able to dedicate this collection of papers to his memory, as a sign of our deep appreciation for his life-time contribution to the discipline of linguistics.

\section{Dr. Francisco Álvarez-Gil}

\section{Dra. Marina Bondi}

Guest Editors

\section{REFERENCES}

Ädel, A. (2005). On the boundaries between evaluation and metadiscourse. In E. Tognini Bonelli \& G. Del Lungo Camiciotti (Eds.), Strategies in academic discourse (pp. 153-162). Amsterdam: John Benjamins.

Ädel, A. (2010). Just to give you kind of a map of where we are going: A taxonomy of metadiscourse in spoken and written academic English. Nordic Journal of English Studies, 9(2), 69-97.

Ädel, A. \& Mauranen, A. (2010). Metadiscourse: Diverse and divided perspectives. Nordic Journal of English Studies, 9(2), 1-11.

Alonso-Almeida, F. (2012). Sentential evidential adverbs and authorial stance in a corpus of English computing articles. Revista de Lingüistica y Lenguas Aplicadas 7, 9-21.

Alonso-Almeida, F. (2015). The functions of seem and parecer in Early Medical Writing. Discourse Studies, 17(2), 121-40.

Alonso-Almeida, F. \& Álvarez-Gil, F. J. (2019). Modal verb categories in CHET. In I. Moskowich, B. Crespo, L. Puente-Castelo \& L. M. Monaco (Eds.), Writing History in Late Modern English: Explorations of the Coruña Corpus (pp. 150-165). Amsterdam: John Benjamins.

Alonso-Almeida, F. \& Álvarez-Gil, F. J. (submitted). Developing argumentation in history texts: Epistemic modality and evidentiality. Pragmalingüística.

Álvarez-Gil, F. J. (2020). A disciplinary analysis of fairly in late modern English scientific writing. In M. L. Carrió-Pastor (Ed.), Corpus Analysis in Different Genres: Academic Discourse and Learner Corpora (pp. 93-107). New York: Routledge.

Bamford, J. \& Bondi, M. (Eds.) (2005). Dialogue within discourse communities. metadiscursive perspectives on Academic Genres. Berlin: De Gruyter. 
Biber, D. \& Finnegan, E. (1989). Styles of stance in English: Lexical and grammatical marking of evidentiality and affect. Text, 9(1), 93-124.

Biber, D., Johansson, S., Leech, G., Conrad, S. \& Finegan, E. (1999). Longman Grammar of Spoken and Written English. Harlow: Longman.

Bondi, M. (2017). What came to be called: Evaluative what and authorial voice in the discourse of history. Text \& Talk, 37, 25-46.

Bondi, M. \& Sezzi, A. (2016). Evidence (re)presentation and evidentials in popular and academic history: Facts and sources speaking for themselves. Kalbotyra Vilniaus Universitetas, 69, 7-28.

Brown, L. (2011). Korean honorifics and politeness in second language learning. Amsterdam: John Benjamins.

Caffi, C. (2007). Mitigation. New York: Elsevier.

Callaghan, M. \& Rothery, J. (1988). Teaching factual writing: A genre-based approach: The report of the DSP Literacy Project, Metropolitan East Region. Metropolitan East Disadvantaged Schools Program.

Carrió-Pastor, M. L. (2012). A contrastive analysis of epistemic modality in scientific English. Revista de Lenguas para Fines Específicos, 18, 115-132.

Carrió-Pastor, M. L. (2016). A contrastive study of interactive metadiscourse in academic papers written in English and in Spanish. In F. Alonso-Almeida, L. Cruz-García \& V. González-Ruiz (Eds.), Corpus-based Studies on Language $V$ arieties (pp. 89-114). Bern: Peter Lang.

Chafe, W. (1986). Evidentiality in English conversation and academic writing. In W. Chafe \& J. Nichols (Eds.), Evidentiality: The linguistic coding of epistemology (pp. 261-272). Norwood: Ablex.

Crismore, A. (1984). The rhetoric of textbooks: Metadiscourse. Curriculum Studies, 16(3), 279-296.

Crismore, A. \& Farnsworth, R. (1989). Mr Darwin and his readers: Exploring interpersonal discourse as a dimension of ethos. Rhetoric Review, 8(1), 91-112.

Cutting, J. (2007). Introduction to Vague language explored. In J. Cutting (Ed.), Vague language explored (pp. 3-17). New York: Palgrave MacMillan. 
Del Lungo Camiciotti, G. (2008). Two polite speech acts from a diachronic perspective. Aspects of the realisation of requesting and undertaking commitments in the nineteenth century commercial community. In A. H. Jucker \& I. Taavitsainen (Eds.), Speech acts in the history of English (pp. 115-131). Amsterdam: John Benjamins.

González, M. (2015). From truth-attesting to intensification: the grammaticalization of Spanish la verdad and Catalan la veritat. Discourse Studies, 17(2), 162-181.

Goodwin, C. (2006). Retrospective and prospective orientation in the construction of argumentative moves. Text \& Talk, 26(4-5), 443-461.

Gotti, M. (2003). Specialised discourse: Linguistic features and changing conventions. Bern: Peter Lang.

Gotti, M. (2008). Investigating specialised discourse. Bern: Peter Lang.

Halliday, M. A. K. (1988). On the language of physical science. In M. Ghadessy (Ed.), Registers of Written English: Situational Factors and Linguistic Features (pp. 162-178). London: Pinter.

Halliday, M. A. K. (1989). Some grammatical problems in scientific English. Australian Review of Applied Linguistics: Genre and Systemic Functional Studies, 5(6), $13-37$.

Halliday, M. A. K. (1990). The construction of knowledge and value in the grammar of scientific discourse: Charles Darwin's The Origin of the Species. In C. De Stasio, M. Gotti \& R. Bonadei (Eds.), La rappresentazione verbale e icónica (pp. $57-$ 80). Milano: Guerini.

Hyland, K. (1997). Scientific claims and community values: Articulating an academic culture. Language and Communication, 17(1), 19-31.

Hyland, K. (1998). Boosting, hedging and the negotiation of academic knowledge, Text \& Talk, 18(3), 349-382.

Hyland, K. (2001). Humble servants of the discipline? Self-mention in research articles. English for Specific Purposes, 20, 207-226.

Hyland, K. (2002). Authority and invisibility: Authorial identity in academic writing. Journal of Pragmatics, 34, 1091-1112.

Hyland, K. (2005). Metadiscourse: Exploring interaction in writing. London: Continuum.

Hyland, K. (2006). English for academic purposes: An advanced resource book. London: Routledge.

Hyland, K. (2009). Academic discourse. London: Continuum. 
Hyland, K. \& Tse, P. (2004). Metadiscourse in academic writing: A reappraisal. Applied linguistics, 25(2), 156-177.

Hyland, K. \& Bondi, M. (Eds.) (2006). Academic discourse across disciplines. Frankfort: Peter Lang.

Humphrey, S., Martin, J. R., Dreyfus, S. \& Mahboob, A. (2010). The 3x3: Setting up a linguistic toolkit for teaching academic writing. In A. Mahboob \& N. K. Knight (Eds.), Appliable Linguistics (pp. 185-199). London: Continuum.

Lave, J. \& Wenger, E. (1991). Situated learning: Legitimate peripheral participation. Cambridge: Cambridge University Press.

Marín Arrese, J. I. (2009). Effective vs. epistemic stance, and subjectivity/intersubjectivity in political discourse. A case study. In A. Tsangalidis \& R. Facchinetti (Eds.), Studies on English modality. In honour of Frank R. Palmer (pp. 23-52). Bern: Peter Lang.

Martín Martín, P. (2008). The mitigation of scientific claims in research papers: A comparative study. International Journal of English Studies, 8, 133-152.

Martin, J. R. (2000). Beyond exchange: Appraisal systems in English. In S. Hunston \& G. Thompson (Eds.), Evaluation in text: Authorial stance and the construction of discourse (pp. 142-175). UK: Oxford University Press.

Martin, J. R. \& White, P. R. (2005). The language of evaluation: Appraisal in English. Basingstoke: Palgrave Macmillan.

Martínez, I. A. (2005). Native and non-native writer's use of first person pronouns in the different sections of biology research articles in English. Journal of Second Language Writing, 14, 174-190.

Mauranen, A. (1993). Cultural differences in academic rhetoric. Frankfurt: Peter Lang.

McNamara, D. S., Louwerse, M. M., Cai, Z. \& Graesser, A. (2014). Automated Evaluation of Text and Discourse with Coh-Metrix. Cambridge: Cambridge University Press.

Moskowich, I. \& Crespo, B. (2014). Stance in present scientific writing, indeed. Evidence from the Coruña Corpus of English scientific writing. TOKEN. A Journal of English Linguistics, 3, 91-113.

Mur-Dueñas, P. (2007). 'I/We focus on...': a cross-cultural analysis of self-mentions in business management research articles. Journal of English for Academic Purposes, 6, 143-162. 
Mur-Dueñas, P. (2011). An intercultural analysis of metadiscourse features in research articles written in English and in Spanish. Journal of Pragmatics, 43, 3068-3079.

Palmer, F. R. (2001). Modality and the English modals. London: Longman.

Peacock, M. (2006). A cross-disciplinary comparison of boosting in research articles. Corpora, 1(1), 61-84.

Pic, E. \& Furmaniak, G. (2012). A study of epistemic modality in academic and popularised discourse: The case of possibility adverbs perhaps, maybe and possibly. Revista de Lenguas para Fines Especificos, 18, 13-44.

Taavitsainen, I. \& Pahta, P. (2013). The corpus of early English Medical writing (1375-1800): A register-specific diachronic corpus for studying the history of scientific writing. In A. Meurman-Solin, V. Marttila, C. Suhr \& J. Tyrkkö (Eds.), Digital editing. Helsinki: Varieng.

Taavitsainen, I., Pahta, P. \& Mäkinen, M. (2006). Towards a corpus-based history of specialised languages. In R. Facchinetti \& M. Rissanen (Eds.), Middle English Medical Texts. Corpus-Based Studies in Diachronic English (pp. 79-94). Bern: Peter Lang.

Tang, R. \& John, S. (1999). The 'I 'in identity: Exploring writer identity in student academic Writing through the first person pronoun. English for Specific Purposes, 18, 23-39.

Vande Kopple, W. (1985). Some exploratory discourse on metadiscourse. College Composition and Communication, 36, 82-93.

Vande Kopple, W. (2002). Metadiscourse, discourse and issues in composition and rhetoric. In E. Barton \& G. Stygall (Eds.), Discourse studies in composition. Cresskill (pp. 91-113). New Jersey: Hampton Press.

Wei, J., Li, Y., Zhou, T. \& Gong, Z. (2016). Studies on metadiscourse since the $3^{\text {rd }}$ millenium. Journal of Education and Practice, 7(9), 194-204.

Williams, J. (1981). Style: Ten lessons in clarity and Grace. Glenview, Illinois: Scott, Foresman and Company. 